\title{
Hunting patterns in tropical forests adjoining the Hkakaborazi National Park, north Myanmar
}

\author{
Madhu Rao, Than Myint, Than Zaw and Saw Htun
}

\begin{abstract}
Hunting for subsistence and trade constitute a major threat to wildlife populations within and outside protected areas in Myanmar. We examined hunting patterns in a forested landscape adjoining the Hkakaborazi National Park in north Myanmar with the aim of generating recommendations to manage hunting. The results described here focus on two issues: the significance of proximity to settlements and markets for prey abundance, and the influence of relative abundance and intrinsic preference on prey offtake. We used strip transect and camera trap surveys to generate relative abundance indices and overall encounter/capture rates for commonly hunted species at four sites that differed in their proximity to settlements and large trading towns. Questionnaires were used to obtain meal records and
\end{abstract}

information on hunting. Encounter and capture rates for hunted species appear to be inversely related to proximity to villages as well as to large, commercial towns. Hunting is indiscriminate, with offtake determined largely by relative abundance rather than intrinsic preference or legislation. Specific management and policy recommendations include the need to monitor the impacts of hunting on vulnerable species, the demarcation of no-take areas, and modification of the legal framework for wildlife conservation.

Keywords Bushmeat, hunting, Myanmar, wild meat, wildlife trade.

This paper contains supplementary material that can only be found online at http:/ /journals.cambridge.org

\section{Introduction}

Hunting and trade in wildlife species have resulted in population declines both within and outside protected areas in South-east Asia (Srikosomatara et al., 1992; Bennett et al., 2000; Lee, 2000; Nooren \& Claridge, 2001; Kaul et al., 2004). Human populations in the region engage in hunting to meet nutritional, economic, cultural and recreational needs. The problem is complex and multidimensional, involving a number of diverse and synergistic factors related to economic well-being, cultural traditions and food security (Robinson \& Bennett, 2000). The continuous growth of human populations, both in numbers and per capita consumption, requires urgent and effective conservation measures to halt the decline of wildlife in the region.

Myanmar (formerly known as Burma) is the largest country on the South-east Asian mainland and shares

Madhu Rao* (Corresponding author) Department of Zoology, Downing Street, Cambridge University, Cambridge, UK. E-mail mrao@wcs.org

Than Myint, Than Zaw and Saw Htun Wildlife Conservation Society Myanmar Program, Yangon, Myanmar.

${ }^{*}$ Current address: Wildlife Conservation Society, 185th Street and S. Blvd., Bronx, New York, NY 10460, USA.

Received 21 January 2004. Revision requested 9 September 2004. Accepted 2 December 2004. its borders with Thailand, Lao PDR, China, India and Bangladesh. The country is governed by a military regime and is subject to international trade and economic sanctions (Steinberg, 2001). Unlike many of its neighbours, Myanmar still contains large areas of relatively intact forest, particularly north of $24^{\circ} \mathrm{N}$, but these resources are under tremendous pressure for exploitation (UNDP/FAO, 1985; Salter, 1994; Global Witness, 2003). The protected area system has increased from $<2 \%$ of the land area in 1996 to $>4.5 \%$ in 2003 , but lack of sufficient park management capacity, both technical and financial, is a significant limitation to effective management (Blower, 1985; Rabinowitz, 1999; Rao et al., 2002).

The Hkakaborazi National Park (Fig. 1) was established in 1998 and covers an area of $3,812 \mathrm{~km}^{2}$; it is the second largest protected area in Myanmar. High levels of species richness and endemism have led to the region being recognized as a conservation hotspot (Myers et al., 2000) and a globally outstanding terrestrial ecoregion (Wikramanayake et al., 2002). The region represents one of the few places in the Indo-Pacific region where potential exists for proactive conservation action to protect threatened species that are rare or declining in neighbouring countries (Dinerstein \& Wikramanayake, 1993; Rabinowitz, 1999; Wikramanayake et al., 2002). The Park consists primarily of large areas of subtropical broadleaved forests but also includes small patches of 


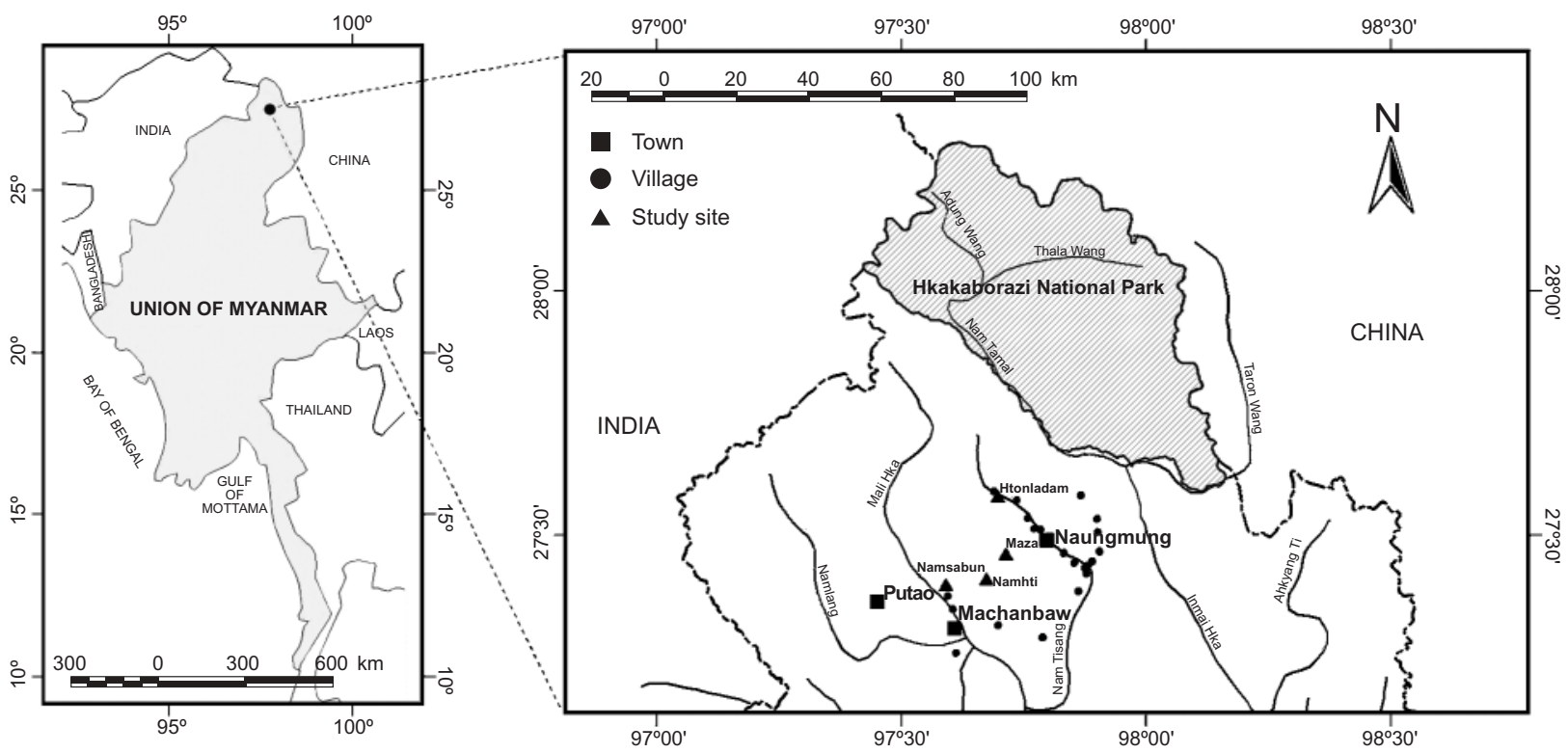

Fig. 1 Map of study sites and location of Hkakaborazi National Park in north Myanmar.

temperate broadleaved forests and sub-alpine conifer forests. The region contains the headwaters of the country's most important river system, the Ayeyarwady, which drains vast expanses of agricultural lands and helps sustain extensive rice production areas in this predominantly agrarian economy.

Forest areas lying south of the Park border and demarcated by the Nam-Tamai River have been proposed for designation as Protected Public Forests. These forests comprise a total area of $690 \mathrm{~km}^{2}$ and include parts of the watersheds of Mali Kha River and southern drainage of Nam Tamai River (Fig. 1). Selective extraction of commercial timber is legally permitted within these protected public forests. Paddy and shifting cultivation, hunting, mining, raising livestock and gathering of diverse non-timber forest products constitute the primary occupations of the relatively low human population in the area. Hunting for subsistence and trade, together with habitat loss due to logging and shifting cultivation, adversely affect biodiversity in north Myanmar (Uga, 1995; Brunner et al., 1998; Rabinowitz, 1998; Lynam, 2003). Hunting is suspected to have resulted in the local extirpation of mammals such as the elephant Elephas maximus, tiger Panthera tigris, rhino Dicerorhinus sumatrensis and gaur Bos gaurus (Milton \& Estes, 1963; Rabinowitz \& Khaing, 1998). However, data on the nature and intensity of current hunting patterns is largely inadequate to inform effective management strategies for threatened species and sites.

We conducted a study to examine general patterns of hunting and wild meat consumption to generate management recommendations for the buffer zone of the
Hkakaborazi National Park. Results presented here comprise a part of the larger study and focus on two issues: the significance of proximity to settlements and markets for prey abundance, and the influence of relative abundance and intrinsic preference on prey offtake.

\section{Legal and institutional framework for conservation}

The Nature and Wildlife Conservation Division (NWCD), created in 1984 and placed within the Forest Department, is primarily responsible for the conservation and management of protected areas in Myanmar. Wildlife conservation legislation enacted in Myanmar in 1994 (the Protection of Wildlife and Protected Areas Law; State Law and Order and Restoration Council, 1994) ensures protection of wild flora and fauna, their habitats and representative ecosystems. Species are afforded varying degrees of protection according to their designation (Ministry of Forestry, 1994): (1) Completely Protected species may not be hunted except for scientific purposes under a special licence; (2) Protected species may be hunted but only with special permission; (3) Seasonally Protected species are subject to traditional subsistence hunting by rural communities only during the open (i.e. non-breeding) season. Hunting is illegal within protected areas but legally allowed elsewhere including, with a licence, buffer zones of protected areas. In reality, however, the Forest Department no longer issues licences, and hence hunting within buffer zones is considered an illegal activity. 
Table 1 Proximity of study sites (Fig. 1) to human settlements and trading towns.

\begin{tabular}{lll}
\hline Study site & $\begin{array}{l}\text { Shortest straight-line } \\
\text { distance to a trading } \\
\text { town }(\mathrm{km})\end{array}$ & $\begin{array}{l}\text { Number of households } \\
\text { (human population size) } \\
\text { within a 10 km radius }\end{array}$ \\
\hline Htonlardam & 17.2 & $131(684)$ \\
Namhti & 16.0 & 0 \\
Maza & 10.8 & $42(229)$ \\
Namsabum & 12.2 & $296(1,315)$ \\
\hline
\end{tabular}

\section{Study area}

The study focused on 26 villages and four forested sites within the Naungmung and Machanbaw townships (Fig. 1) using questionnaires, track/sign and camera-trap surveys from May 2002 to May 2003. The four forested sites included Htonlardam, Namhti, Maza and Namsabum. The sites differed in the number of villages within a $10 \mathrm{~km}$ radius of these sites and distance to the nearest large trading town, which was assumed to be relevant to wildlife trade (Table 1). The habitat is primarily subtropical broadleaved forest with patches of shifting cultivation, agricultural and degraded lands. Forests are characterized by a thick understorey and dominant canopy trees that include species belonging to the genera Castaneopsis, Terminalia, Shorea and Pterospermum. The altitude in the study area ranges from $409 \mathrm{~m}$ (Putao) to 1,874 m (Mt Langabum).

\section{Methods}

\section{Strip transect surveys}

Strip transect surveys for direct encounters or tracks / signs were used to estimate relative encounter rates for species at the four forested sites (Htonlardam, Namhti, Maza and Namsabum). Four $1 \mathrm{~km}$ long and $2 \mathrm{~m}$ wide permanent transects were cut at each of the four sites at a distance of at least $500 \mathrm{~m}$ from each other and $250 \mathrm{~m}$ from village edges. Transects were orientated radially with respect to the villages. The strip widths for recording wildlife sightings and tracks/signs were $20 \mathrm{~m}$ and $2 \mathrm{~m}$ respectively. Each transect was divided into five $200 \mathrm{~m}$ sections. Direct observations of wildlife and counts of tracks and signs (faeces, soil scrapes, signs of tusks and antlers, vocalizations, burrows, ground clearing (for pheasants Lophura and Tragopan spp.) and exposed soil mounds (for porcupines Hystrix brachyura) were recorded by observers walking along a transect at a speed of $c .1 \mathrm{~km} \mathrm{hr}^{-1}$. There were no apparent differences in the characteristics of the different transect sites as all had similar vegetation and terrain. Observers walked each transect at 06.00-09.00 and 15.00-18.00, the times when animals were most active. Between May 2002 and May 2003 a total of $361 \mathrm{~km}$ of transect lines were surveyed at the four sites in both wet and dry seasons. Survey data were used to estimate: (a) average encounter rates per $\mathrm{km}$ of transect surveyed at each of the four sites, and (b) overall relative abundance indices for 14 mammal species $(>1 \mathrm{~kg}$ ) across all four sites. Count data were analyzed using a one-way ANOVA. Comparisons were made of relative encounter rates across the four sites using distance to trading towns as the explanatory variable.

\section{Camera trap surveys}

Given that direct observations of wildlife are typically rare in these forest types, camera traps were deployed to obtain additional information on relative abundance of species at the four sites. Each camera trap was positioned near a salt lick or fruiting tree close to the end of every transect, with 16 traps deployed at any one time. Camera traps were left in the forest for 30-35 days and deployed at 64 different positions at the four sites over the entire study period for a total of 1,238 trap nights. Independent events for camera trap captures of individual animal species were defined following $\mathrm{O}^{\prime}$ Brien et al. (2003). The number of trap nights was calculated for each camera location from the day the camera was mounted until the day it was retrieved. Following camera retrieval, films were developed, and we identified each photo of an animal to species, and recorded time and date. We scored each photo as an independent or non-independent event based on the following definition of an independent event: (1) consecutive photographs of different individuals of the same or different species; (2) consecutive photographs of individuals of the same species taken more than 0.5 hours apart; (3) non-consecutive photos of individuals of the same species. We used the number of independent photographs of a species per 100 trap nights to calculate an index of relative abundance. Camera trap surveys at the four sites were used to estimate: (a) average capture rates per 100 trap nights per site (based on number of independent events as defined above); and (b) relative abundance indices for 19 mammal and one bird species.

\section{Questionnaire-based surveys}

\section{Hunter interviews}

Questionnaires (Appendices 1-2) were used to obtain data on 220 hunting incidents from hunters in 12 villages. All records were obtained by interviewing hunters who had just returned from hunts or within 5 days of their last hunt. Logistical constraints made it difficult to randomly sample hunts. Recorded variables included the duration 
of the hunt, number of people who went on the hunt, type and number of weapons used, prey species captured, primary occupation, and reasons for hunting. Average $\mathrm{kg}$ of offtake per species per hunting incident were calculated from the 220 incidents. Species' offtake levels $(\mathrm{kg})$ were calculated from the hunt records. The influence of relative abundance or preference on prey offtake for 14 harvested species with records from the camera trap surveys was examined with regression analysis. To determine the relationship between intrinsic hunter preference for species and actual offtake of such species, we correlated ranks of actual offtake with preference ranks determined through interviews. All statistical analyses were conducted using Minitab (Release 14, 2004, Minitab Inc., State College, USA).

\section{Meal records}

We obtained meal records using questionnaires (Appendix 3) during visits to households (after Bennett et al., 2000). To determine the prevalence of wild meat as a dietary component, we obtained independent meal records from 704 different households spread across 26 villages. Five categories of food items were identified: wild meat species, vegetables, fish (fresh and preserved), livestock (eggs, meat of cows, buffaloes, pigs and chickens) and others (soya, rice, noodles, etc.). Every meal was scored for the presence of each food type. Meal records were collected from the person who prepared the meals in the house and related to the most recent meal consumed by the family. All records could be classified as either the first or last meal of the day. Data collection was from September 2002 to May 2003. Logistical constraints made it difficult to randomly select households as many families were busy with farming responsibilities during the crop-planting season, but overall at least $20 \%$ of the households in each of the villages were surveyed. We calculated the percentage of all meals containing wild meat, vegetables, fish, livestock and other foods.

Seven of the 26 villages were visited over at least 2 months of the peak dry season (December-January) and 2 months of the peak wet season (AugustSeptember) and yielded 347 meal records that constituted a subset of the larger dataset of 704 records. We examined seasonal variation in consumption of the three main sources of animal protein, fish, livestock and wild meat using this subset.

\section{Results}

\section{Hunting pressure and prey abundance}

Table 2 provides the relative abundance index estimates derived for 20 species from camera trap surveys and 14 species from strip transect surveys. The overall relative abundance estimates for nine species with records from both strip transect and camera trap surveys were found to be significantly correlated (Pearson's correlation coefficient $=0.796, \mathrm{P}=0.01$ ).

There were significant differences in mean encounter rate (total number of direct observations, tracks and signs per $\mathrm{km}$ of transect) among the four sites ( $F=7.22$, $n=361, \mathrm{P}<0.0001)$. Comparisons of encounter rates derived from strip transect surveys with capture rates (total number of independent exposures per site) derived from camera trap surveys revealed similar trends (Fig. 2). The two sites with higher encounter and capture rates (Htonlardam and Namhti) are farther away from the large trading towns of Machanbaw and Naunmung, and also have fewer settlements within a $10 \mathrm{~km}$ radius than Maza and Namsabum (with lower encounter and capture rates) (Table 1). Among the four sites, the lowest encounter and capture rates were recorded at Namsabum, a site in relatively close proximity to a major trading town (Machanbaw) and with the largest human population within a $10 \mathrm{~km}$ radius. Questionnaire surveys and discussions determined that villagers would walk $10-15 \mathrm{~km}$ for hunting as well as trading purposes.

\section{Determinants of prey offtake}

A regression analysis of offtake levels against relative abundance estimates (capture rate per 100 trap nights) derived from camera trap surveys for 14 species was significant (Fig. 3). Residuals were not influenced by protection status of the species. Relatively more abundant species appear, therefore, to be captured more frequently than less abundant ones, all else being equal. Table 2 lists the number of individuals of 19 species in offtake records.

Twelve commonly targeted species ranked on the basis of preference by hunters were not significantly correlated with levels of offtake (Spearman's Rank Correlation, $\left.R_{s}=-0.574, \mathrm{P}=0.065\right)$. However, this analysis did not take into account natural variation in species abundance and assumed equal abundance and trapability of species. The three species most sought by hunters (tigers, bears Ursus thibetanus, and pangolins Manis javanica) were either totally absent from offtake records, in the case of tigers, or ranked far lower in frequency of occurrence than other less sought-after species such as barking deer Muntiacus muntjac, primates Macaca spp. and Trachypithecus spp. and wild pigs Sus scrofa.

Of the 19 species of wildlife recorded in 220 independent hunting events, nine were Totally Protected, three were Protected, one (barking deer) was Seasonally Protected and six were unprotected. In addition, seven and four species are listed on CITES Appendices I and II (CITES, 2005), respectively, and 13 on the IUCN Red List 
Table 2 Relative abundance indices derived from strip transect and camera trap surveys (nine species had records from both types of survey), offtake records for harvested species, IUCN Red List status (IUCN, 2004), and listing on CITES Appendices I and II (CITES, 2005).

\begin{tabular}{|c|c|c|c|c|c|}
\hline Species & $\begin{array}{l}\text { Relative abundance } \\
\text { index (capture rate } \\
\text { per } 100 \text { trap nights) }\end{array}$ & $\begin{array}{l}\text { Relative abundance } \\
\text { index (encounter rate } \\
\text { per km) }\end{array}$ & $\begin{array}{l}\text { Number of } \\
\text { individuals in } \\
\text { offtake records }\end{array}$ & $\begin{array}{l}\text { Red List } \\
\text { status }^{1}\end{array}$ & $\begin{array}{l}\text { CITES } \\
\text { Appendix }\end{array}$ \\
\hline Barking deer Muntiacus muntjac & 18.08 & 3.32 & 145 & & \\
\hline Malayan porcupine Hystrix brachyura & 12.43 & 0.76 & 15 & VU & \\
\hline Wild pig Sus scrofa & 10.73 & 0.42 & 32 & & \\
\hline Yellow-throated marten Martes flavigula & 6.77 & 0.01 & 2 & & \\
\hline Clouded leopard Neofelis nebulosa & 6.21 & & 1 & VU & I \\
\hline Stump-tailed macaque Macaca arctoides & 6.21 & & & VU & II \\
\hline Serow Naemorhedus sumatraensis & 5.08 & 0.45 & 16 & VU & I \\
\hline Malayan sun-bear Helarctos malayanus & 3.39 & 0.07 & 11 & DD & I \\
\hline Wild $\operatorname{dog}$ Cuon alpinus & 3.39 & 0.03 & 8 & EN & II \\
\hline Masked palm civet Paguma larvata & 2.82 & 0.15 & 17 & & \\
\hline Capped langur Trachypithecus pileatus & 2.26 & 0.04 & 29 & EN & I \\
\hline Kalij pheasant Lophura leucomelanos & 1.13 & & & & \\
\hline Rhesus macaque Macaca mulatta & 4.52 & & 65 & $\mathrm{LR} / \mathrm{nt}$ & \\
\hline Leopard cat Felis bengalensis & 3.95 & & 1 & & II \\
\hline Brush-tailed porcupine Atherurus macrourus & 3.39 & & & & \\
\hline Golden cat Felis temminkii & 1.69 & & 2 & VU & I \\
\hline Leaf deer Muntiacus putaoensis & 1.13 & & 2 & & \\
\hline Binturong Arctictis binturong & 0.56 & & & & \\
\hline Hog badger Arctonyx collaris & 0.56 & & & & \\
\hline Spotted linsang Prionodon pardicolor & 0.56 & & & & I \\
\hline Himalayan squirrel Dremomys lokriah & & 0.46 & & & \\
\hline Hoolock gibbon Bunopithecus hoolock & & 0.43 & 9 & EN & I \\
\hline Rufous necked hornbill Aceros nipalensis & & 0.18 & & VU & \\
\hline Pangolin Manis javanica & & 0.07 & 7 & $\mathrm{LR} / \mathrm{nt}$ & II \\
\hline Jungle fowl Gallus gallus & & 0.01 & & & \\
\hline Jungle cat Felis chaus & & & 7 & & \\
\hline Sambhar deer Cervus unicolor & & & 8 & & \\
\hline Impressed tortoise Manouria impressa & & & 3 & VU & \\
\hline
\end{tabular}

${ }^{1}$ EN, Endangered; VU, Vulnerable; LR/nt, Lower Risk/ near threatened; DD, Data Deficient

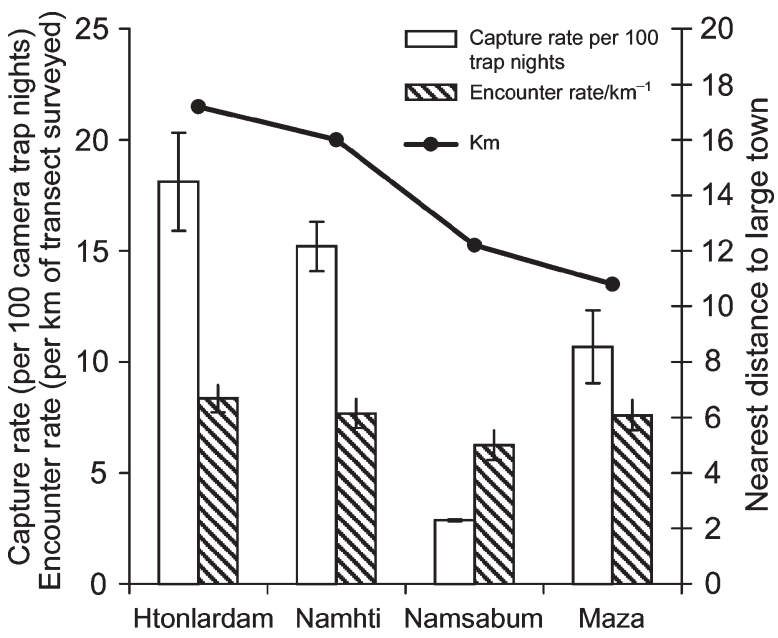

Fig. 2 Capture rates of species (number of independent exposures per 100 trap nights) from camera trap surveys, and encounter rates of tracks and signs (per $\mathrm{km}$ of transect surveyed) from strip-transect surveys \pm SE (bars), and nearest distances between study sites and the trading towns of Naung Mung and Machanbaw.
(IUCN, 2004). Of the 220 independent hunting incidents $6 \%$ involved professional hunters, $57 \%$ involved people engaged in both hunting and farming, 30\% were farmers by profession, and $7 \%$ pursued other professions. Hunting seems to commonly occur in the peak winter months (November-February) following crop planting. Duration of hunts varied greatly, ranging from a few hours to $>3$ weeks. The majority of hunting was with snares, traps (bamboo and jaw traps) and crossbows. A total of 4,384 weapons were used in the 220 hunting incidents; $72 \%$ of these were nylon and steel snares, $21 \%$ bamboo traps, $5 \%$ crossbows, and $1 \%$ each were guns and jaw traps.

\section{Meal analyses}

The mean percentage ( $\pm 95 \%$ confidence interval) of meals containing vegetables $(60 \pm 4.5 \%)$ was greater than those containing fish $(23.2 \pm 5.4 \%)$, wild meat $(8.9 \pm 3.3 \%)$, livestock $(6.2 \pm 1.7 \%)$ and other food items $(1.7 \pm 1.4 \%)$. Wild fish appeared to be the most prevalent 


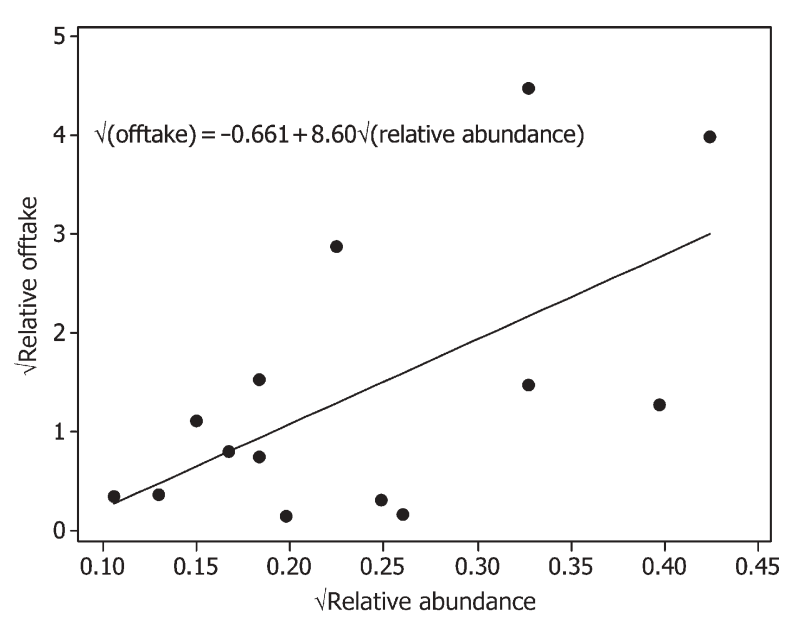

Fig. 3 Regression analysis of relative offtake (kg per hunting incident) against relative abundance (encounter rates of tracks and signs per km of transect), both square-root transformed, for 14 commonly hunted species $(F=6.82, \mathrm{P}=0.023)$.

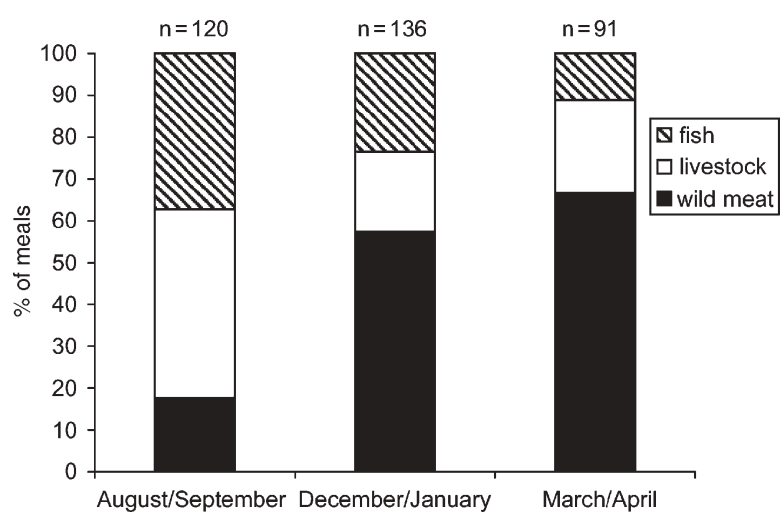

Fig. 4 Seasonal variation in consumption patterns of fish, livestock, and wild meat obtained from 347 meal records (Appendix 3).

source of animal protein relative to wild or domestic meat (livestock). Seasonal variation in dietary composition of fish, domestic livestock and wild meat in a subset of 347 meal records revealed relatively higher frequency of wild meat consumption compared to fish and domestic livestock meat in the winter dry season months (December-April) and reduced consumption of wild meat in the months of August and September, which is the planting season (Fig. 4). Barking deer (64\%), primates $(10 \%)$ and wild pigs $(7 \%)$ were the top three species recorded in the 124 meals containing wild meat. Mammal species recorded in meals are listed in Table 3.

\section{Discussion}

Hunting in forest areas adjoining the Hkakaborazi National Park is influenced by complex biological,
Table 3 Frequency of occurrence of wild species in meal records obtained from 704 households in 26 villages.

\begin{tabular}{lc}
\hline Species & Frequency of occurrence \\
\hline M. muntjac & 79 \\
M. mulatta, M. arctoides, T. pileatus & 12 \\
S. scrofa & 9 \\
H. brachyura & 8 \\
N. sumatraensis & 4 \\
C. unicolor & 4 \\
M. javanica & 3 \\
F. bengalensis & 3 \\
Rattus sp. & 2 \\
\hline
\end{tabular}

socioeconomic and institutional factors. Obtaining relevant information for management is difficult because of resource constraints (human and financial), the inaccessibility of sites, and concerns about the reliability of information obtained through questionnaires. To effectively address the problem of wildlife hunting, obtaining data on the distribution, density and rates of change in populations of hunted species is a clear research priority (Milner-Gulland et al., 2003). Estimation of population trends of targeted species is particularly difficult at sites where they are hunted and where animals are either extremely shy and/or occur at low densities (Nichols \& Karanth, 2002). In studies such as ours, given the limitations of access to sites and generally low detection probability, the use of track and sign encounter rates to estimate abundance indices is inevitable. However, the utility of such indices depends on the nature of the relationship between the index and actual abundance (Conroy, 1996; O'Brien et al., 2003), in addition to problems associated with uncertainty in drawing inferences from index statistics (Yoccoz et al., 2001; Nichols \& Karanth, 2002). More importantly, for validity, relative abundance estimates derived from camera traps need to be compared with independent density estimates derived from line transect methods (Jennelle et al., 2002; O'Brien et al., 2003).

In this study indices obtained from camera trap surveys were significantly correlated with those obtained from strip-transect surveys, but indices for individual species could not be calibrated and hence cannot be assumed to reflect real differences in abundance and distribution. However, observed patterns of variation in encounter and capture rates of targeted species with distance from human settlements, and thus markets, is potentially related to hunting pressure. This inverse relationship between abundance of targeted wildlife and accessibility or proximity to human settlements or markets has been documented elsewhere (Clayton et al., 1997; Peres \& Lake, 2003). Human population growth, coupled with greater accessibility and fragmentation of 
forested areas, will inevitably lead to continued increase in hunting pressure and subsequent declines in wildlife densities (Chin \& Bennett, 2000; Wilkie et al., 2000). Knowledge of factors influencing hunting pressure, such as the increased demand for wildlife products, the ability to purchase weapons or opportunities to engage in a cash economy is vital for developing effective conservation strategies. Demarcation of no-take areas could potentially serve as source areas for hunted wildlife in other parts of the buffer zone (Bodmer, 2000).

The issue of sustainability is key to determining the impacts of hunting on wildlife resources and potential consequences for human populations dependent on these resources (Freese, 1998; Robinson \& Bennett, 2000). However, although the type of information needed to calculate indices of sustainability (Robinson \& Redford, 1994) was beyond the scope of our study, there are several indicators that warrant the need for caution. Our results suggested that hunting is indiscriminate, with offtake determined largely by relative abundance, rather than intrinsic preferences or legislation. In general, it appears that hunters are opportunistic, maximizing their return rather than selecting species according to considerations of sustainability. Similar trends have been reported by other studies in the region (Duckworth et al., 1999; Lee, 2000).

The predominant use of snares is indicative of the indiscriminate capture of wildlife. Wire snares take a wide variety of species and sizes of animals and, if not regularly checked, result in waste (Lee, 2000; Noss, 2000). Preferred species such as musk deer Moschus fuscus, tiger, otter Lutra lutra and pangolin appear to be less common or completely absent compared to nonpreferred species in records of actual offtake, perhaps suggestive of a gradual shift in hunting patterns driven by increasing rarity or local extirpations of preferred species. High value species such as tigers, rhinos and otters already appear to be extremely rare or locally extinct (Myanmar Forest Department, 2003). Our data indicate the need for monitoring the impacts of hunting on threatened species, given that hunted populations could collapse without showing a period of gradually declining harvests (Barnes, 2002). Simple methods for assessing the sustainability of hunting, which can be easily applied by protected area managers, are urgently needed (Milner-Gulland et al., 2003).

To effectively manage hunting it is useful to distinguish between the relative significance of hunting for subsistence and commercial trade. We were unable to obtain reliable information on this given the illegality of hunting and general reluctance of villagers to divulge complete information (Kaul et al., 2004). In Myanmar there is an expansive, informal and largely illegal parallel economy in which wildlife trade plays a part, although the trade has not been quantified. There is evidence to suggest a significant trade across the border with China (Li \& Wang, 1998; Yi Ming et al., 2000) and to other areas, including Thailand, through Mandalay, a major commercial centre south-west of the study area (Martin, 1997; Davidson, 1999). There is need for greater enforcement and awareness efforts in large commercial towns, as well as border areas, in addition to research on patterns of trade.

In South and South-east Asia there is considerable geographic variation in the degree of dependence on wild meat in rural diets (Bennett et al., 2000; Lee, 2000; Kaul et al., 2004). Our results suggest that wild meat is less prevalent as a source of animal protein compared to fish but more prevalent relative to meat from livestock. Our analysis of seasonal variation in dietary composition suggests that people consume wild meat when it is available (mostly in the dry season) and other forms of meat when it is not. However, it is unclear if wild meat consumption patterns reflect actual food/protein scarcity during the winter months or if patterns are influenced more strongly by the fact that farmers have more time to hunt during the crop growing season, when fields require little attention (Kaul et al., 2004).

In general, distinguishing dependence on wildlife from use of the resource (which is influenced by preference rather than dependence) is relevant in the design of appropriate conservation strategies (Milner-Gulland et al., 2003). Factors related to agricultural productivity, livestock ownership, perceived agricultural risks, wealth, and access to alternative sources of food and income could potentially affect patterns of wildlife offtake (Pattanayak \& Sills, 2001; Loibooki et al., 2002; de Merode et al., 2004). Yet a key factor influencing the collection of relevant information through questionnaires and interviews is the common problem of reliability of acquired information. Villagers are frequently hesitant to divulge information, fearing reprisal or other forms of enforcement action. Overcoming this critical obstacle through trust-building activities over the long-term is a clear necessity for effective management of hunting.

A strong legislative framework is also key to the successful management of hunting. Legislation relevant to wildlife conservation in Myanmar is inadequate, often ambiguous, and rarely properly enforced (Pant, 1998). Our results indicate that offtake of species is independent of protection status and highlight the need for legislative reform and proper enforcement of national legislation. Given that Myanmar has been a CITES signatory since 1997, CITES-enabling legislation needs to be introduced.

Specific management and policy recommendations that emerge from our study are: Firstly, demarcation and enforcement of no-take areas within the buffer zone 
of the Hkakaborazi National Park could be one approach to ensure long-term sustainability of hunting in the area (Bodmer, 2000; Milner-Gulland et al., 2003). Secondly, monitoring will be the core of any management strategy; variables to monitor include annual offtake levels, wildlife, and sustainability of hunting for threatened species. Thirdly, devising a system to regulate the use of weapons and ammunition in hunting could help enhance longterm sustainability. Fourthly, awareness of conservation laws, protected species and use restrictions in and around protected areas needs to be enhanced. Finally, strengthening the legal framework for conservation is key to the effective management of hunting in the area.

\section{Acknowledgements}

The study was funded by the Wildlife Conservation Society and the US Fish and Wildlife Service (Grant No. 98210-1-G085). We would like to thank the Ministry of Forestry, Yangon for permission to conduct the study, U Thein Aung, warden of the Hkakaborazi National Park, and his staff for logistical assistance, and Kyaw Tint Latt for assistance with Fig. 1. Phil McGowan is thanked for his assistance in identification of pheasant species. We would also like to thank Alan Rabinowitz, Arlyne Johnson, Phil McGowan and three anonymous referees for comments that improved the manuscript.

\section{References}

Barnes, R.F.W. (2002) The bushmeat boom and bust in West and Central Africa. Oryx , 36, 236-242.

Barnett, R. (2000) Food for Thought: The Utilization of Wild Meat in Eastern and Southern Africa. TRAFFIC East/Southern Africa, Nairobi, Kenya.

Bennett, E.L., Nyaoi, A.J. \& Sompud, J. (2000) Saving Borneo's bacon: the sustainability of hunting in Sarawak and Sabah. In Sustainability of Hunting in Tropical Forests (eds J.G. Robinson \& E.L. Bennett), pp. 305-324. Columbia University Press, New York, USA.

Blower, J. (1985) Conservation priorities in Burma. Oryx, 19, 79-85.

Bodmer, R. (2000) Integrating hunting and protected areas in the Amazon. In Future Priorities for the Conservation of Mammals: Has the Panda had its Day? (eds N. Dunstone \& A. Entwistle), pp. 277-290. Cambridge University Press, Cambridge, UK.

Brunner, J., Talbott, K. \& Elkin, C. (1998) Logging Burma's Frontier Forests: Resources and the Regime. World Resources Institute, Washington, DC, USA.

Caughley, G. (1977) Analysis of Vertebrate Populations. Wiley, New York, USA.

Chin, C.L.M. \& Bennett, E.L. (2000) Beside the beaten track: effects of increased accessibility on wildlife and patterns of hunting in Sarawak. In Borneo 2000: Environment, Conservation and Land (ed. M. Leigh), pp. 29-40. Institute of South East Asian Studies, Universiti Malaysia Sarawak, Kuching, Sarawak, Malaysia.

CITES (2005) The CITES Appendices. Http:/ / www.cites.org/ eng/append/appendices.shtml [accessed 3 December 2003].
Clayton, L., Keeling, M. \& Milner-Gulland, E.J. (1997) Bringing home the bacon: a spatial model of wild pig hunting in Sulawesi, Indonesia. Ecological Applications, 7, 642-652.

Conroy, M. J. (1996) Abundance indices. In Measuring and Monitoring Biological Diversity: Standard Methods for Mammals (eds D.E. Wilson, F.R. Cole, J.D. Nichols, R. Rudran \& M. Foster), pp. 179-192. Smithsonian Institution Press, Washington, DC, USA.

Davidson, P. (1999) Spotcheck of wildlife on sale in a Myanmar Market. TRAFFIC Bulletin, 17, 98

De Merode, E., Homewood, K. \& Cowlishaw, G. (2004) The value of bushmeat and other wild foods to rural households living in extreme poverty in Democratic Republic of Congo. Biological Conservation, 118, 573-581.

Dinerstein, E. \& Wikramanayake, E. (1993) Beyond "hotspots": how to prioritize investments to conserve biodiversity in the IndoPacific Region. Conservation Biology, 7, 53-65.

Duckworth, J.W., Salter, R.E. \& Khounboline, K. (1999) Wildlife in Lao PDR. 1999 Status Report. IUCN, Vientiane, Lao PDR.

Freese, C. H. (1998) Wild Species as Commodities. Managing Markets and Ecosystems for Sustainability. Island Press, Washington, DC, USA.

Global Witness (2003) A Conflict of Interests. The Uncertain Future of Burma's Forests. A Briefing Document by Global Witness. Global Witness, London, UK.

IUCN (2004) IUCN Red List of Threatened Species. IUCN, Gland, Switzerland [http:/ / www.redlist.org, accessed 10 March 2005].

Jennelle, C.S., Runge, M.C. \& Mackenzie, D.I. (2002) The use of photographic rates to estimate densities of tigers and other cryptic mammals: a comment on misleading conclusions. Animal Conservation, 5, 119-120.

Kaul, R., Hilaludin, Jandrotia, J.S. \& McGowan, P.J.K. (2004) Hunting of large mammals and pheasants in the Western Indian Himalaya. Oryx, 38, 1-6.

Lee, R. J. (2000) Impact of subsistence hunting in North Sulawesi, Indonesia, and conservation options. In Sustainability of Hunting in Tropical Forests (eds J.G. Robinson \& E.L. Bennett), pp. 455-472. Columbia University Press, New York, USA.

Li, W. \& Wang, H. (1998) Wildlife trade in Yunnan Province, China, at the border with Vietnam. TRAFFIC Bulletin, 18, 21-29.

Loibooki, M., Hofer, H., Campbell, K.L.I. \& East, M.L. (2002) Bushmeat hunting by communities adjacent to the Serengeti National Park, Tanzania: the importance of livestock ownership and alternative sources of protein and income. Environmental Conservation, 29, 391-398.

Martin, E.B. (1997) Wildlife products for sale in Myanmar. Traffic Bulletin, 17, 33-44.

Milner-Gulland, E.J., Bennett, E.L. \& the SCB 2002 Annual Meeting Wild Meat Group (2003) Trends in Ecology and Evolution, 18, 351-357.

Milton, O. \& Estes, R.D. (1963) Burma Wildlife Survey: 1959-1960. Special Publication No. 15. Unpublished report prepared for IUCN and the American Committee for International Wildlife Protection, New York, USA.

Ministry of Forestry (1994) Notification Number 583/94 Dated 26 October 1994. List of Protected Animals. Yangon, Burma.

Myanmar Forest Department (2003) A National Tiger Action Plan for the Union of Myanmar, Myanmar Forest Department. Ministry of Forestry, Yangon, Myanmar.

Myers, N., Mittermeier, R.A., Mittermeier, C.G., da Fonseca, G.A.B. \& Kent, J. (2000) Biodiversity hotspots for conservation priorities. Nature, 403, 853-858. 
Nichols, J.D. \& Karanth, K.U. (2002) Statistical concepts: Indices of Relative Abundance. In Monitoring Tigers and their Prey. A Manual for Researchers, Managers and Conservationists in Tropical Asia (eds K.U.Karanth \& J.D. Nichols), pp. 61-70. Centre for Wildlife Studies, Bangalore, India.

Nooren, H. \& Claridge, G. (2001) Wildlife Trade in Laos: The End of the Game. Netherlands Committee for IUCN, Amsterdam, The Netherlands.

Noss, A. (2000) Cable snares and nets in the Central African Republic. In Sustainability of Hunting in Tropical Forests (eds J.G. Robinson \& E.L. Bennett) pp. 282-304. Columbia University Press, New York, USA.

O'Brien, T., Kinnaird, M. \& Wibisono, H. (2003) Crouching tigers, hidden prey: Sumatran tiger and prey populations in a tropical forest landscape. Animal Conservation, 6, 131-139.

Pant, R. (1998) Transboundary Cooperation in Biodiversity Conservation in the Eastern Himalaya Ecoregion: A Policy Gap Analysis. World Wildlife Fund-Nepal, Kathmandu, Nepal.

Pattanayak, S.K. \& Sills, E.O. (2001) Do tropical forests provide natural insurance? The microeconomics of non-timber forest product collection in the Brazilian Amazon. Land Economics, 77, 595-613.

Peres, C.A. \& Lake, I.R. (2003) Extent of non-timber resource extraction in tropical forests: accessibility to game vertebrates by hunters in the Amazon Basin. Conservation Biology, 17, 521-535.

Rabinowitz, A. (1998) Status of the tiger in North Myanmar. Tigerpaper, 25, 15-19.

Rabinowitz, A. (1999) The status of the Indochinese tiger: separating fact from fiction. In Riding the Tiger: Tiger Conservation in Human-dominated Landscapes (eds J. Seidensticker, S. Christie \& P. Jackson), pp. 148-165. Cambridge University Press, Cambridge, UK.

Rabinowitz, A. \& Khaing, S.T. (1998) Status of selected mammal species in North Myanmar. Oryx, 32, 201-208.

Rao, M., Rabinowitz, A. \& Khaing, S.T. (2002) Status of Protected Areas in Myanmar, with recommendations for conservation planning. Conservation Biology, 16, 360-368.

Robinson, J. \& Bennett, E.L. (eds) (2000) Hunting for Sustainability in Tropical Forests. Columbia University Press, New York, USA.

Robinson, J.G. \& Redford, K.H. (1994) Measuring the sustainability of hunting in tropical forests. Oryx, 28, 249-256.

Salter, R. (1994) Priorities for Further Development of the Protected Area System in Myanmar. Report for Conservation and Wildlife Sanctuary Mission MYA/91/015, Yangon, Myanmar.

Srikosomatara, S., Siripholdej, B. \& Suteethorn,V. (1992) Wildlife trade in Lao P.D.R. and between Lao P.D.R. and Thailand. Natural History Bulletin of the Siam Society, 40, 1-47.
State Law and Order Restoration Council (1994) The Protection of Wildlife and Protected Areas Law (Law No. 6/94). 8th June 1994. Yangon, Myanmar.

Steinberg, D. I. (2001) Burma: The State of Myanmar. Georgetown University Press, Washington, DC, USA.

Uga, U. (1995) Situation of Biological Diversity Conservation in Myanmar. Ministry of Forestry, Yangon, Myanmar.

UNDP/FAO (1985) Nature Conservation and National Parks: Burma. Survey Data and Conservation Priorities. Technical Report I. UNDP/FAO, Rome, Italy.

Wikramanayake, E.D., Dinerstein, E., Loucks, C.J., Olson, D.M., Morrison, J., Lamoreux, J., McKnight, M. \& Hedao, P. (2002) The Terrestrial Ecoregions of the Indo-Pacific: A Conservation Assessment. Island Press, Washington, DC, USA.

Wilkie, D., Shaw, E., Rotberg, F., Morelli, G. \& Auzel, P. (2000) Roads, development, and conservation in the Congo basin. Conservation Biology, 14, 1614-1622.

Yi-Ming, L., Zenxiang, G., Xinhai, L., Sung, W. \& Niemela, J. (2000) Illegal wildlife trade in the Himalayan region of China. Biodiversity and Conservation, 9, 901-918.

Yoccoz, N.G., Nichols, J.D. \& Boulinier, T. (2001) Monitoring of biological diversity in space and time. Trends in Ecology and Evolution, 16, 446-453.

\section{Appendices 1-3}

The appendices for this article are available online at http:/ /journals.cambridge.org

\section{Biographical sketches}

Madhu Rao has been involved in wildlife conservation in Myanmar since 1998. Her research interests include factors driving wildlife use, conservation planning and protected area effectiveness, and she is involved in the creation of a network of protected areas in north Myanmar.

Than Myint has been involved in conservation projects in Myanmar since 1997. He has provided training in wildlife field techniques for protected area staff and is currently involved in wildlife and protected area management.

Than Zaw has undertaken extensive field work in north Myanmar to examine hunting patterns in the Hkakaborazi National Park and the Hponghkhan Razi Wildlife Sanctuary.

Saw Htun is involved in projects related to hunting and wildlife use in north Myanmar, and has previously examined hunting patterns in the Hkakaborazi National Park and the Hponghkan Razi Wildlife Sanctuary. 